DOI https://doi.org/10.36059/978-966-397-158-2/271-290

\title{
IMPACT OF CRIMEA'S ANNEXATION ON SECURITY POLICIES IN EUROPE: ADDRESING CHALLENGES AND MANAGING VULNERABILITIES BY THE EU AND VISEGRAD GROUP
}

\section{Dvornichenko D.}

\section{INTRODUCTION}

Five years have passed since the Russian Federation annexed Crimea. The annexation of Crimea by the Kremlin turned out to be the most serious breach of European borders since the Second World War. Russia violated the fundamental principles of international law, its international obligations and bilateral agreements with Ukraine. The annexation has sharply increased instability of the European security environment, created new dividing lines and greatly enhanced the risk of the destruction of the existing world order. A proper understanding of how the annexation of Crimea affected Europe's security policy and shaped its response can provide essential insights to measure the effectiveness of its approach to ensuring the European security and preventing similar crises on a regional scale.

The following paper will assess how the annexation of Crimea affected the EU and its four member-states' policy. By taking an interdisciplinary and critical look at the impact the annexation of Crimea made on Europe, the paper aims to provide answers to the following questions:

1) How coherent and effective is the non-recognition, sanction-based and information security policy of the EU?

2) How has the annexation of Crimea impacted the narrative and political decisions in security field adopted by Russia understanders and Russia opponents among of the Visegrad Group?

3) How does the position of the EU and Visegrad Group contribute to the European security?

At the end of the paper the conclusions and recommendations on how to ensure Europe's own political, energetic and information security are presented.

\section{The Annexation of Crimea: Background and Implications}

The strategic importance of the Crimean peninsula was realized thousands of years ago. Its geopolitical location almost in the centre of the 
Black Sea between the Caucasus and Southern Europe as well as the wealth of natural resources makes its strategically important. A significant portion of Russia's navy stationed in Sevastopol and the ethnic diversity of Crimea with the largest population of ethnic Russians within Ukraine and a strong Muslim minority of the Crimean Tatars turned it into the most sensitive issue in Ukraine-Russia relations which could easily explode.

At different times Crimea was owned by the Tauris, Cimmerians, Greeks, Scythians, Romans, Huns, Goths, Bulgarians, Tatars, Slavs and other peoples. Its history as part of the Russian Empire started in 1783 when Catherine the Great annexed it from the Ottoman Empire. In 1921, Crimea became the Crimean Autonomous Soviet Socialist Republic, part of the Soviet Union. Thirty-three years later, in 1954, Nikita Khrushchev transferred Crimea to Ukraine in a move hailed as a noble act on behalf of the Russian people. When Ukraine held a referendum in December 1991, $54 \%$ of the Crimean residents favoured the independence from the Soviet Union. It was a majority, but the lowest one found in Ukraine. Thus Crimea became part of independent Ukraine with significant autonomy including its own constitution and parliament. In 1997, Ukraine and Russia signed a bilateral Treaty on Friendship, Cooperation and Partnership, which formally allowed Russia to keep its Black Sea Fleet in Sevastopol. From 1997 to 2014, the situation in Crimea was considered under control.

However, the second decade of the XXI century has marked a shift in Russian military mindset. A refusal to accept Western dominance alongside with a more active form of resistance has been deeply embedded in a new doctrine articulated by Chief of Russian General Staff Valery Gerasimov in his article «The Value of Science is in the Foresight». Based on the lessons of the Georgia conflict, he described a framework of the new operational concept as the role of «Non-Military Methods in the Resolution of Interstate Conflicts» ${ }^{1}$. According to V. Gerasimov, Russia heavily relies on proxy forces, both paramilitary and cyber, supported by media institutions and companies, Spetsnaz and Cossack fighters to conduct different types of operations, like unconventional, information, psychological and cyber operations, as well as security forces assistance and strategic communication. Due to the fact that the proxy forces consist of a mixture of Russians and ethnic Russians abroad, Russia not only exploits social conditions, but also cultural and linguistic factors in former Soviet states and

1 Герасимов В. Ценность науки в предвидении. Военно-Промышленный Курьер. 2013 // www.vpk-news.ru/articles/14632 
at home to create proxy forces ${ }^{2}$. The open use of forces often under the guise of peacekeeping and crisis regulation is resorted to only at a certain phase, primarily for the achievement of final success in the conflict. Altogether, the new generation warfare concept by V. Gerasimov has six phases which proved to be a successful approach in taking over Crimea from Ukraine.

Main part in the operation orchestrated by Russia was the media campaign to gain support in Crimea and to isolate the government of Ukraine. Television and the Internet were the dominant news media in Ukraine. The Russian information campaign started with the comparison of the Ukrainian government and their Western allies to Nazis, gays, Jews and other groups of people that Russia claimed were part of the conspiracy ${ }^{3}$. Russia showed swastikas on billboards and in the media to compare the Ukrainian government to Nazi Germany. Russian media used past events to emphasize how aggressive NATO and the West were and how these powers violated agreements on NATO expansion into Eastern Europe.

The annexation of Crimea has serious implications for Ukraine and Europe in all areas. In the economic area, the annexation of Crimea and further Russia's military actions in Donbas led to the displacement of 1.5 million registered Ukrainians, who have become a challenge not only for Ukrainian economy but also for the neighbouring EU member-states. In the energetic area, the annexation of Crimea led to the breakdown of energetic ties between Ukraine and Russia which might pose a challenge to the energy security of the other European states benefitting from transit routes via Ukraine's and their territory. In the military area, Russia can now block the Black Sea Straits in the South-West strategic direction, using forces located on the Crimean peninsula. In the geopolitical area, the annexation of Crimea demonstrated that European states security might be also challenged by Russia.

Although the Crimean scenario is unlikely to be repeated in other European countries, Russia's efforts to interfere in their internal affairs (especially in those countries which either have Russian-speaking population or common energetic and economic interests) via disinformation campaigns with the purpose to destabilize the situation and challenge the unity of the EU will be more assiduous. That actualizes the search for a proper response of the EU to the Kremlin's actions against Ukraine's territorial integrity.

2 Selhorst T. Russia's Perception Warfare. Militaire Spectator. 2016 // https://www.militairespectator.nl/thema/strategie-operaties/artikel/russias-perception-warfare

${ }^{3}$ Yuhas A. Russian Propaganda over the Crimea and the Ukraine: How Does it Work? The Guardian of 17 March 2014 // https://www.theguardian.com/world/2014/mar/17/the The the Crimea-crisis-russia-propaganda-media 


\section{EU's Response to the Annexation of Crimea}

The EU has demonstrated its strong commitment to support Ukraine since 2014. The EU conclusions, high-level statements and declarations have been used to address actions against Ukraine's territorial integrity, human rights violations and the infringement of navigational rights in Ukraine's territorial waters.

The situation in Crimea was first addressed by the EU during the extraordinary meeting of the EU Heads of State on 6March, 2014. In the joint statement, the EU leaders condemned Russia's unprovoked violation of the Ukrainian sovereignty and territorial integrity and called on Russia to immediately withdraw its armed forces and allow immediate access for international monitors ${ }^{4}$.

The violation of Ukrainian sovereignty and territorial integrity has become the key message in the numerous EU documents especially when the attention of the international community shifted from Crimea to Eastern Ukraine. However, since the outbreak of war in eastern Ukraine, the EU has been rather vocal in its support of any negotiating format in regard to the conflict in Donbas, whereas the issue of Crimea remains non-negotiable. In this regard there are serious doubts as to the consistency of the EU's position towards the annexed peninsula as «the EU insists on dividing the two issues, Donbas and Crimea» and omitting «the Crimean case from the current discussions» ${ }^{5}$.

The human rights violations have also been a topic of consistently keen interest of the EU. Since the Russian attack against Crimea, the European Parliament has paid close attention to the situation of the Crimean Tatars. Meanwhile, the European Parliament resolutions adopted in 2014 only vaguely addressed the human rights-related activities. The rapidly developing territorial conflict overshadowed other concerns. Five years on from the illegal annexation of the Autonomous Republic of Crimea and the city of Sevastopol by the Russian Federation, the High Representative Federica Mogherini on behalf of the EU adopted the Declaration on the Autonomous Republic of Crimea and the city of Sevastopol which states that the human rights situation in the Crimean peninsula has significantly deteriorated. Residents of the peninsula face systematic restrictions of

\footnotetext{
${ }^{4}$ Extraordinary meeting of EU Heads of State or Government on Ukraine of 6 March 2014 // https://www.consilium.europa.eu/en/meetings/european-council/2014/03/06/

${ }^{5}$ Ivashchenko-Stadnik K., Petrov R., Rieker P., Russo A. Implementation of the EU's crisis response in Ukraine. EUNPACK working paper. 2018 // http://www.eunpack.eu/sites/ default/files/publications/2018-01-31\%20D6.3\%20Working\%20paper\%20on\% 20implementation \%20of\%20EU\%20crisis\%20response\%20in\%20Ukraine.pdf
} 
fundamental freedoms, such as freedom of expression, religion or belief and association and the right to peaceful assembly. The Declaration also confirms the grave violations of rights of the Crimean Tatars through the shutting down of the Crimean Tatar media outlets, the banning of the activities of the Mejlis, their self-governing body, and the persecution of its leaders and members of their community ${ }^{6}$. Unfortunately, the Declaration contains nothing but the EU expectations that Russia will reverse its decisions and end the pressure on the Crimean Tatar community.

The infringement of navigational rights in Ukraine's territorial waters has also appeared to be one of the topics in the declarations and resolutions initiated by the EU. On 24 October 2018, the European Parliament adopted the Resolution which expressed its very serious concern about the volatile security situation in the Sea of Azov and condemned the excessive stopping and inspection of commercial vessels, including both Ukrainian ships and those with flags of third-party states. ${ }^{7}$ The resolution had no effect on further Russia actions in the Sea of Azov and did not stop the Kremlin from using force a month later when Russian forces fired on and seized two Ukrainian gunboats and one tug after the Ukrainian vessels tried to pass under the Kerch Strait Bridge.

In December 2018, following the events of 25 November, the European Parliament adopted the resolution on the implementation of the EU Association Agreement with Ukraine. It strongly condemned the deliberate act of aggression by the Russian Federation against Ukraine on 25 November 2018 in the Kerch Strait and called on the EU and its Member States to close access to EU ports for Russian ships coming from the Sea of Azov if Russia did not re-establish freedom of navigation through the Kerch Strait and in the Sea of Azov. ${ }^{8}$

On 17 June 2019, the Council adopted the Conclusions on the Black Sea confirming again that the EU policy decisions and its non-recognition policy on the illegal annexation of Crimea are fundamental to the EU's approach to

\footnotetext{
${ }^{6}$ Declaration by the High Representative Federica Mogherini on behalf of the EU on the Autonomous Republic of Crimea and the city of Sevastopol of 17March 2019 // https://www.consilium.europa.eu/en/press/press-releases/2019/03/17/declaration-by-the-highrepresentative-federica-mogherini-on-behalf-of-the-eu-on-the-autonomous-republic-of-crimeaand-the-city-of-sevastopol/

${ }^{7}$ European Parliament resolution $\{2018 / 2870$ (RSP)) on the situation in the Sea of Azov of 24 October 2018 // http://www.europarl.europa.eu/doceo/document/RC-8-2018-0493_EN.html

${ }^{8}$ European Parliament resolution (2017/2283(INI)) on the implementation of the EU Association Agreement with Ukraine of 12 December 2018 // http://www.europarl.europa.eu/ doceo/document/TA-8-2018-0518_EN.html?redirect
} 
regional cooperation in the Black Sea area ${ }^{9}$. However, the document remains silent on what exactly the EU is willing to do about Russia's unlawful actions in the Kerch Strait.

The non-recognition policy is rather seldom introduced in isolation from other foreign policy instruments such as restrictive measures. Since March 2014, the EU has progressively imposed restrictive measures against Russia in response to the annexation of Crimea. The first set of restrictive measures was imposed in 2014 against 21 Russian and Ukrainian officials responsible for actions threatening Ukraine's territorial integrity. The same year the EU adopted a package of targeted economic sanctions which included a ban on imports of goods originating in Crimea or Sevastopol unless they have Ukrainian certificates; a prohibition to invest in the Crimea, a ban to buy real estate or entities in the Crimea, finance the Crimean companies or supply related services, a ban to invest in infrastructure projects in the following sectors: transport; telecommunications; energy, exploration and production of oil, gas and mineral resources; a ban on providing tourism services in the Crimea; a ban on exporting transport, telecommunications and resources to the Crimea; a ban on providing technical assistance, brokering, construction or engineering services related to infrastructure in the Crimea.

In late November 2018, a new Crimean crisis challenged the international community. Russian coast guard ships opened fire on a group of vessels of the Ukrainian Navy in international waters as they were leaving the Kerch Strait ${ }^{10}$. However, it took the EU almost 4 months to renew sanctions over actions on 15 March 2019 to add eight Russian officials to the list of those subject to restrictive measures in respect of actions undermining or threatening the territorial integrity, sovereignty and independence of Ukraine $^{11}$. On 20 June 2019, Council prolonged the restrictive measures introduced in response to the illegal annexation of Crimea and Sevastopol by Russia until 23 June 2020.

However, there are particular weak spots in the sanctions regime. The EU is not expected to only condemn the party of the conflict but rather demonstrate how much pain can be tolerated. According to Paul

\footnotetext{
${ }^{9}$ Council Conclusions on the EU's engagement to the Black Sea regional cooperation of 17 June 2019 // https://www.consilium.europa.eu/media/39779/st10219-en19.pdf

${ }_{10}$ Ukraine urges EU to impose new sanctions on Russia over attack near Kerch Strait. UNIAN. 26 November 2018, // https://www.unian.info/politics/10351809-ukraine-urgeseu-to-impose-new-sanctions-on-russia-over-attack-near-kerch-strait.html

${ }^{11}$ Ukraine: EU responds to escalation at the Kerch Strait and the Sea of Azov, and renews sanctions over actions against Ukraine's territorial integrity of 15 March 2019 // https://www.consilium.europa.eu/en/press/press-releases/2019/03/15/ukraine-eu-responds-toescalation-at-the-kerch-straits-and-the-azov-sea-and-renews-sanctions-over-actions-againstukraine-s-territorial-integrity/
} 
Kalinichenko, the EU sanctions in response to the actions threatening Ukraine's territorial integrity and Russia's countersanctions have frozen negotiations and consequently have not achieved anything. ${ }^{12}$ The sanctions have neither stopped the annexation nor restrained Russia from taking further aggressive steps.

Besides, tighter implementation is required. In 2015 and 2016, Siemens sold gas turbines to Russia, four of which were later installed in Russiaannexed the Crimea. In May 2018, the construction of Nord Stream 2, which will deliver gas to Europe from northern Russia's Yamal Peninsula, started. Vessels from several EU member states have repeatedly infringed the sanctions by docking in the Crimean ports. The sanctions remain rather soft and thus fail to destroy the relations between the EU and Russia in such areas as energy, investments and manufactured goods trade.

Last but not least, most sanctions have been imposed in regard to such violations of international law as actions against Ukraine's territorial integrity, although breaches of human rights have been present so far. The EU addresses human rights violations by adopting particular conclusions and declarations rather than deploying restrictive measures. Hopefully, after the adoption of the EU Global Human Rights Act further sanctions in response to human rights violations in Crimea will be considered.

The annexation of Crimea has forced the EU to reconsider its own its own security approach due to new challenges and threats. Since 2014 Russia has been active in influencing public opinion and justifying its actions in Ukraine in 2014 by means of cyber activities. On the one hand, these activities, mainly but not exclusively expressed through cyberattacks, are targeted at the EU institutions and the governments of the European Union member-states. On the other hand, the citizens of the European states are also one of the targets of the Russia's cyber actions such as dissemination of propaganda and disinformation.

Since 2014 the EU has taken active measures to reduce its internal vulnerabilities in response to hybrid warfare, in the face of the challenges from Russia's disinformation and propaganda. The European Parliament in November 2016 adopted a resolution stating that «Russia's goal is to distort truths, provoke doubt, divide member states, engineer a strategic split between the European Union and its North American partners, discredit the EU institutions and transatlantic partnerships as well as to undermine and erode the European narrative based on democratic values, human rights and

12 Kalinichenko P. Post-Crimean Twister: Russia, the EU and the Law of Sanctions. Russian Law Journal. 2017. No 5(3). P. 9-28 // https://doi.org/10.17589/2309-8678-2017-53-9-28 
the rule of law» ${ }^{13}$. In 2017, The Council agreed to develop a framework for a joint EU diplomatic response to malicious cyber activities, the «cyber diplomacy toolbox» ${ }^{14}$. On 17 May 2019, the Council adopted the Council Decision (CFSP) 2019/797 concerning restrictive measures (sanctions) «to deter and respond to cyber-attacks which constitute an external threat to the EU or its member states, including cyber-attacks against third States or international organisations» ${ }^{15}$.

As Moscow is doing its best to deliver «the same disinformation stories in as many languages as possible through as many channels as possible ${ }^{16}$, the EU has also taken formal steps towards tackling this issue. The European security experts have appealed to the EU High Representative, Federica Mogherini to start taking the Russian disinformation threat seriously in 2015. ${ }^{17}$ Later that year, the European Council asked the EU High Representative for an action plan regarding strategic communication targeting Russia's ongoing disinformation efforts ${ }^{18}$. These actions resulted in the establishment of the East StratCom task force, set up in 2015 under the European External Action Service (EEAS). StratCom collects examples of pro-Kremlin false information articles in Europe and issues its weekly newsletters on the platform «EU vs Disinfo». As «EU vs Disinfo» sees the fight against disinformation as an extension of the EU's common foreign and security policy in the East, it is concentrated primarily against Russian propaganda efforts, especially in Ukraine, and the Russian state media's reporting on the EU. The task force has an additional task and aims also at promoting the European Union's policies mostly in the EU's eastern

\footnotetext{
${ }^{13}$ European Parliament Resolution of 23 November 2016 on EU Strategic Communication to Counteract Propaganda against it by Third Parties // https://www.europarl.europa.eu/ doceo/document/TA-8-2016-0441_EN.html

${ }^{14}$ Council Conclusions. Brussels on a Framework for a Joint EU Diplomatic Response to Malicious Cyber Activities of 7 June 2017 // http://data.consilium.europa.eu/doc/document/ST9916-2017-INIT/en/pdf

${ }^{15}$ Council Decision (CFSP) 2019/797 of 17 May 2019 concerning restrictive measures against cyber-attacks threatening the Union or its Member States // https://eurlex.europa.eu/legal-content/GA/TXT/?uri=CELEX:32019D0797

${ }^{16}$ Stone, J. 2018. Russian disinformation campaign has been 'extremely successful' in Europe, warns EU. Independent. 17 January 2018 // http://www.independent.co.uk/ news/uk/politics/russian-fakenews-disinformation-europe-putin-trump-eu-european-parliamentcommission-a8164526.html

${ }^{17}$ European Values. Open Letter of European security experts to Federica Mogherini: Please start taking the Russian disinformation threat seriously // http://www.europeanvalues.net/ mogherini/

${ }_{18}$ European Parliament. Disinformation, 'fake news' and the EU's response 2017. // http://www.europarl.europa.eu/RegData/etudes/ ATAG/2017/614584/EPRS_ATA(2017)614584_EN.pdf
} 
neighbourhood by addressing disinformation circulating within the EU that repeats Kremlin talking points. The latter is subject to harsh criticism as by meddling into the entire European information space and commenting on domestic media the European External Action Service's East Stratcom Task Force is increasingly emerging as a domestic censorship machine which goes far beyond the EEAS expertise.

In order to make the StratCom more effective, the European Parliament called for the development of «criteria for measuring the efficiency of its work and ensuring sufficient financing and adequate staffing of the East StratCom Task Force» ${ }^{19}$. The suggestion to provide adequate budgetary resources for the task force was highly welcomed as the team experienced sufficient difficulties with funding. Initially the East StratCom Task Force did not dispose its own budget but depended on the existing EU strategic communication budget. ${ }^{20}$

Further efforts were made in 2018, when the European Council endorsed the Action Plan against Disinformation which stated that the East StratCom Task Force analysed and put the spotlight on over 4,500 examples of disinformation by the Russian Federation. The same year, the Task Force was additionally granted $€ 1.1$ million for its work to address Russia's disinformation. In 2019, the budget increases to $€ 3$ million. From January 2019, the budget is being directed to ensure professional media monitoring, disinformation analysis and data analysis. The objective is to gain a more comprehensive, regular and reliable picture of Russia's disinformation campaigns $^{21}$.

\section{Security Policy of the Visegrad Group after the Annexation of Crimea}

The present study will focus on evaluating public statements and actions taken by the Visegrad Four with the aim to assess the impact of annexation of Crimea on their security policies and the level of their alignment with the official Brussels course.

${ }^{19}$ European Parliament resolution of 23 November 2016 on EU strategic communication to counteract propaganda against it by third parties // http://www.europarl.europa.eu/doceo/ document/TA-8-2016-0441_EN.html

${ }^{20}$ Benková L.. The Rise of Russian Disinformation in Europe. FOKUS. \#3. 2018 // https://www.aies.at/download/2018/AIES-Fokus_2018-03.pdf

${ }_{21}$ Questions and Answers about the East StratCom Task Force // https://eeas.europa.eu/headquarters/headquarters-homepage/2116/-questions-and-answersabout-the-east-stratcom-task-force_en 


\subsection{Security Policy of Poland after the Annexation of Crimea}

Poland has been at the forefront of the European response to Russia's aggression. Unlike other Visegrad Group states, condemnation of Russian actions against territorial integrity of Ukraine is seen on an all-country political scale, drawing criticism from the right, left, and centre. The annexation of Crimea increased fears towards Russia that have always been very strong in Poland. Naturally, Poland has shown full support to sanctions against Russia and non-recognition policy. The annexation of Crimea has also affected Poland's internal policies and its perception of Europe's security system.

Poland has been firm on abandoning Russian natural gas imports in favour of alternative import sources from Denmark and Norway. The LNG terminal focused on the imports from Qatar, Norway and the United States was put into operation in 2016. In 2018, Poland announced plans to revive the Baltic Pipe Project - construction of an underwater pipeline in order to pump Norwegian North Sea offshore gas $^{22}$.

Poland has also increased its military expenses from 1,6\% GDP in 2013 to 2,2\% in 2015. As a part of Operation Atlantic Resolve, American soldiers have been deployed in Poland along with tanks and heavy equipment ${ }^{23}$ serving as a response to the militarization of Kaliningrad Oblast. Since the annexation of Crimea Polish state leadership has redoubled efforts to convince their partners and allies in the West that the enhancement of NATO Eastern flank is a very urgent need. Polish diplomacy instigated a demarche oriented toward persuading the leading NATO powers that the cheapest and easiest manner to deter potential future Russian invasion on the Transatlantic Alliance is to deploy additional troops to the countries which are the most susceptible to invasion ${ }^{24}$.

The Concept of Defence of the Republic of Poland adopted in 2017 considers the «aggressive policy of the Russian Federation, including the use of such tools as disinformation campaigns against other countries» as

\footnotetext{
${ }^{22}$ Miroslavov O. Poland refuses LNG terminal in favor of the gas corridor with Norway. RuBaltic. 6 March 2018 // https://www.rubaltic.ru/articles/06032018-poland-refuses-lngterminal-in-favor-of-the-gas-corridor-to-norway/

${ }^{23}$ Kremlin Watch Report. How do European democracies react to Russian aggression? Review of shifts in strategic \& policy documents of EU28 following Russian aggression against Ukraine. 2017// https://www.europeanvalues.net/wp-content/uploads/2017/04/How-doEuropean-democracies-react-to-Russian-aggression.pdf

${ }^{24}$ Furgacz P. Poland's Military Security Policy in the Context of the Russian Ukrainian War: Change or Continuity, Ante Portas - Studia nad Bezpieczeństwem, 2017. No $1 / /$ file:///D:/\%D0\%97\%D0\%B0\%D0\%B3\%D1\%80\%D1\%83\%D0\%B7\%D0\%BA\%D0\%B8/AP.V III_Furgacz\%20(1).pdf
} 
one of the main threats and challenges. However, the Concept does not contain any precise developments or tasks regarding information security. Meanwhile, the same year Polish Prime Minister Beata Szydło announced the creation of a department of cyber security within the Chancellery of the Prime Minister ${ }^{25}$.

Fight against Russian information influence has become a topic of regular discussions. In 2015, Poland started to draft the Cyber-security Doctrine of Republic of Poland as a response to the increase in hybrid threats, propaganda, disinformation, and psychological influence operation. The Doctrine is supposed to be the key document clarifying the scope of responsibilities and the mode of cooperation and coordination between the government, private institutions, and citizens. The document is still in the drafting phase.

In March 2017, the Polish Ministry of Digital Affairs published the draft Cyber Security Strategy for the years 2017-2022 as an extensive update of the 2013 edition. On 7 August, 2019, it was replaced by the Poland's Cybersecurity Strategy for 2019-2024.

Polish authorities publicly recognise the disinformation operations from Russia and consider them as a major threat at the national and international level $^{26}$. Among the most prominent steps in this field are the cancellation of the broadcasting license of the Warsaw-based station Radio Hobby that rebroadcasted programming produced in Polish by Radio Sputnik and the launch of the consultations on disinformation in Warsaw in 2016.

However, the civil society efforts in combatting Russia's disinformation are not so strong as in other Visegrad states. Poland is flourished by the nationalists and the groups that appeal to anti-immigrant sentiments, PolishUkrainian history or support the anti-Ukrainian demonstrations. Despite being marginalised, pro-Russian activists are getting more and more effective in spreading disinformation. Nowadays, the most vocal are the antiimmigrant groups. With the tacit consent from the government, the far-right nationalist groups act more freely and their activities are more visible to the general public. Setting up the Ukrainian flag on fire during the commemoration of Polish Independence Day in 2016 is the best example ${ }^{27}$.

25 Polish PM to set up new cybersecurity department. Radio Poland. 2017 // http://www.thenews.pl/1/9/Artykul/329562,Polish-PM-to-set-up-new-cybersecurity-department

${ }^{26}$ Minister Witold Waszczykowski opens conference on disinformation. MFA. 2016 // http://www.msz.gov.pl/en/news/minister_witold_waszczykowski_opens_conference_on_disinf ormation

${ }^{27}$ Milo D., Klingova K. Vulnerability Index: Subversive Russian Influence in Central Europe. GLOBSEC Policy Institute 2017 // https://www.globsec.org/wp-content/uploads/ 2017/08/globsec-vulnerability-index.pdf 
There are only a few NGOs monitoring the disinformation narratives in Poland and actively debunking them, e.g. CEPA has been producing weekly briefs on country-specific applications of Russian disinformation content and techniques and the effectiveness or weakness of propaganda.

\subsection{Security Policy of the Czech Republic after the Annexation of Crimea}

In the Czech Republic, several documents have been adopted to address the security issues after Crimea's annexation. The Security Strategy of the Czech Republic, adopted in 2015, warns about «threats of a military nature, stemming from the aspirations of some states that, more than ever, tend to show a disregard for the international order and basic principles of international law in their pursuit of power. Driven by such aspirations, these actors substantially reinforce their military capabilities, including offensive cyber capabilities. ${ }^{28}$ The document also mentions, that the Czech Republic includes among the relevant security threats also those that have no direct impact on its own security, but do threaten its allies.

In 2016, the Czech Government launched a process called «Audit of National Security», analysing 11 areas of internal security for blind spots in the security architecture «in context of events in Ukraine and with the emerging awareness that the Czech Republic has also been facing hybrid threats ${ }^{29}$. Among the 11 areas, there were two relevant for Russian influence: «Influence of Foreign Powers» and «Hybrid Threats». The Audit of National Security presented particular suggestions for strengthening the resilience of the Czech Republic such as the establishment of the Centre Against Terrorism and Hybrid Threats (CTHH) within the Ministry of Internal Affairs, a unit of 20 experts monitoring the spread of disinformation in the Czech media and disinformation campaigns in general, especially coming from Russia and the Islamic State. Its task is to monitor the disinformation campaigns, send early warning alerts on politically relevant disinformation and train other parts of the state administration with special program focused on this threat ${ }^{30}$. The Audit also highlighted the need for creation of a system of education for public officials to make them more

\footnotetext{
${ }^{28}$ Security Strategy of the Czech Republic. Ministry of Defence \& Armed Forces of the Czech Republic. $2015 \quad / / \quad$ http://www.army.cz/images/id_8001_9000/8503/ Security_Strategy_2015.pdf

Disinformation Resilience in Central and Eastern Europe. Kyiv. 2018 // http://prismua.org/wp-content/uploads/2018/06/DRI_CEE_2018.pdf

${ }^{30}$ Milo D., Klingova K. Vulnerability Index: Subversive Russian Influence in Central Europe. GLOBSEC Policy Institute 2017 // https://www.globsec.org/wpcontent/uploads/2017/08/globsec-vulnerability-index.pdf
} 
resilient towards foreign influence, launching active media strategies for important democratic institutions or measures concerning media law ${ }^{31}$.

However, concerning the practical steps, there are a lot of gaps and insufficiencies. Although the existing documents describe the threat well, they are not focused enough on practical measures. The establishment of CTHH is the only recommendation which has been implemented so far by the state.

The Annual Report of the Security Information Service for $2016^{32}$, an intelligence institution active within the Czech Republic, states that the Czech Republic is one of the primary targets of Russian hybrid campaign in the context of the Ukrainian crisis. As a part of subversive activities aimed against the sovereignty and territorial integrity of Ukraine, Russia and its intelligence services coordinated and financed operations of so-called nongovernmental organizations, which conducted grey and black active measures against territorial integrity of Ukraine. Representatives of «nongovernmental» entities directly or indirectly controlled by Russia and its intelligence services systematically attempted to gain support of Czech parliamentary and non-parliamentary political parties and officials from top state administrative authorities. The report also mentions APT28/Sofacy campaign which is currently the most visible Russian cyberespionage campaign with various areas of activities - ranging from principal areas, such as diplomacy and defence, to science and research and academia. The Security Information Service attributed the responsibility for attacks against Czech military research institution and several European Foreign Affairs Ministries in European states to APT28/Sofacy.

In the last couple of years, a few civil society projects and initiatives have been established to ensure the resilience of Czech society in the context of disinformation campaigns. The Czech think-tank European Values issues weekly newsletter the Kremlin Watch. The Association for International Affairs together with StopFake.org launched a Czech version of StopFake website. Another fact-checking initiative is project 'Demagog' whose primary goal is to teach the public to think critically about information provided by anybody as well as to raise awareness about the fact that disinformation can be used in public space. The launch of successful initiatives aimed at active monitoring of the influence of the disinformation and Russian propaganda has become possible due to the well-established and

31 National Security Audit. Government of the Czech Republic. 2016 // https://www.vlada.cz/assets/media-centrum/aktualne/Audit-narodni-bezpecnosti-20161201.pdf

32 Annual Report of the Security Information Service of the Czech Republic. 2016 // https://www.bis.cz/public/site/bis.cz/content/vyrocni-zpravy/en/ar2016en.pdf 
active civil society in the Czech Republic which according to the Vulnerability Index $2017^{33}$ ranked as the second most resilient towards the foreign influence.

\subsection{Security Policy of Slovakia after the Annexation of Crimea}

Slovakia does not consider Russian influence a threat, therefore, does not securitize disinformation campaigns and does not give a priority to strategic counter-measures. Besides, a «pragmatic» approach of Slovakia's leadership who regards Russia as an inevitable, unavoidable partner upon which Slovakia's economic development is dependent does not contribute to take adequate steps in combatting Russia's propaganda.

In this regard, there is no surprise, that in Slovakia, no specific document has been adopted to address the issue of security since 2005. The Slovak National Security Strategy was developed in 2005 and has not been updated since then. As such, it reflects the security threats existing at the time of its creation and the post $9 / 11$ era.

Currently, a new National Security Strategy has been drafted. The document claims that the security environment has deteriorated significantly due to the rising ambition of some states to the use of military force. It points to the specific manifestations of deteriorated security environment such as the promotion of foreign-political interests by some states and their use of military force to disrupt the territorial integrity of other states that is a direct reference to Russia ${ }^{34}$. It also emphasizes the negative impact of hybrid activities that both state and non-state actors can use to achieve specific goals without a formal declaration of war.

In this regard the most active forces in Slovakia in managing vulnerabilities are not the government but civil society. Slovak civil society ranked as the least vulnerable to external influence within the Visegrad Group $^{35}$ and the most active in addressing the influence of disinformation and Russian propaganda. A number of civic organizations and think tanks are currently taking the most visible countermeasures and activities in Slovakia. The annual Forum Against Propaganda (Fórum proti propaganda),

\footnotetext{
${ }^{33}$ Milo D., Klingova K. Vulnerability Index: Subversive Russian Influence in Central Europe. GLOBSEC Policy Institute 2017 // https://www.globsec.org/wpcontent/uploads/2017/08/globsec-vulnerability-index.pdf

${ }^{34}$ Nečej E., Žilinčík S. Analysis of the draft of Security Strategy of Slovak Republic 2017: Comparison with strategic documents of Czech Republic and Poland. STRATPOL. 2017 // https://www.stratpol.sk/wp-content/uploads/2017/08/fSSSR-2017-ENG-v-final-OND-final.pdf

${ }^{35}$ Milo D., Klingova K. Vulnerability Index: Subversive Russian Influence in Central Europe. GLOBSEC Policy Institute 2017 // https://www.globsec.org/wp-content/uploads/ 2017/08/globsec-vulnerability-index.pdf
} 
which is organized as a side event of the Slovak Security Forum, brings together individuals and organizations interested in the topic of disinformation from the public, private and NGO sectors. This platform serves as a place for the exchange of ideas and better coordination of joint efforts in counter measures. The GLOBSEC Policy Institute based in Bratislava issues Information War Monitor, analysing the narratives and disinformation spread in the Czech Republic, Hungary and Slovakia. The Slovak Security Policy Institute has been translating Disinformation Digest of EEAS' Strategic Communication Unit into Slovak language.

\subsection{Security Policy of Hungary after the Annexation of Crimea}

Hungary's latest document on its security policy, Governmental decree $1035 / 2012$, was adopted in $2012^{36}$. It neither mentions Russia not takes into account the new regional architecture of the international relations after 2014. Since then, the strategy has not been updated.

Hungarian Prime Minister Viktor Orban is considered the key political ally of the Kremlin who is sympathetic towards the behaviour of the Russian Federation and thus promotes the narratives used to justify Russia's occupation of the Crimea.

Hungary has two largest opposition parties, the socialist Magyar Szocialista Párt which is considered neutral, and the far-right Jobbik, which is openly pro-Russian. This is compounded by the strong economic ties between Hungary and Russia, especially in the energy sector, and the fact that the Hungarian government is openly critical to the EU sanctions on Russia.

There is no surprise, that according to the GLOBSEC Vulnerability Index, Hungary is the most vulnerable country in the Visegrad group to subversive Russian influence ${ }^{37}$. Although there are some efforts from the non-governmental organisations to manage the country's vulnerability to foreign influence (among which Political Capital is the most influential), there is no thematic debunking site in Hungary.

Hungary is not only reluctant to counteract Russia's threat but also actively deepens cooperation with it. The Russian disinformation centres are welcomed. In April 2017 Orban's government allowed Debrecen University to establish a Russkiy Mir Center, providing a EUR 50,000 grant ${ }^{38}$. There are also NGOs directly involved in spreading Russian views. Honfoglalás

\footnotetext{
${ }^{36}$ Hungary's National Security Strategy. 2012 // https://www.eda.europa.eu/docs/defaultsource/documents/hungary-national-security-strategy-2012.pdf

${ }^{37}$ Milo D., Klingova K. Vulnerability Index: Subversive Russian Influence in Central Europe. GLOBSEC Policy Institute 2017/ / https://www.globsec.org/wpcontent/uploads/2017/08/globsec-vulnerability-index.pdf

${ }^{38}$ KrekóP., Győri L. Hungary: A State Captured by Russia. Heinrich Böll Foundation. 2017 // https://www.boell.de/en/2017/10/11/hungary-state-captured-russia
} 
2000 and the Nationalist Social Democrats are Hungarian organizations supporting the government and its pro-Russian foreign policy, including the organisation of rallies supporting Russian-Hungarian friendship. Furthermore, both of these organizations were founded by the Friends of Vladimir Putin Circle. According to the press release, the Friends of Vladimir Putin Circle was established to «inform the population on the incredibly successful work of the Russian president ${ }^{39}$.

\section{CONCLUSIONS}

The annexation of Crimea by the Kremlin has become a test for the EU. So far the EU has managed to develop a non-recognition and sanction-based approach towards Russia's actions in Crimea. It has also made certain efforts in tackling Russia's propaganda and disinformation. However, there are certain doubts whether this response is really an effective means of deterrence. It has neither led to the return of Crimea to Ukraine nor stopped Kremlin's further aggressive actions in the Sea of Azov. The only consideration that occupies the minds of the EU officials is how to save the face and keep on implementing ambitious energy projects in collaboration with Russia. That reveals a number of weaknesses and hidden reputational risks in the EU's response to the security challenges in its nearest neighbourhood.

All the Visegrad Group states differ in how they define and address security threats. They experience current political regime changes, rely on different institutional and technical capacities, as well as develop distinct relationships with Russia. The security challenges management remains rather state-centralized in all four states. The engagement with civic society, research centres and private stakeholders is underdeveloped which results in their vulnerability to foreign, particularly Russia's, influence. Although the EU-level adopted documents as well as the launch of the East StratCom Task Force allow for a greater cooperation among the Visegrad Group states in tackling foreign influence, such initiatives are seriously challenged by domestic political regimes. In this regard, we can hardly expect an effective common approach to security in the region in the nearest future which is only beneficial for Moscow, which focuses on bilateral relations with particular Visegrad Group states and actively seeks to exploit differences between them.

The annexation of Crimea concerns the most basic principles of Europe and therefore should be considered in a much broader context as a test of endurance for it. The challenge for the EU member states is how to ensure

\footnotetext{
${ }^{39}$ Milo D., Klingova K. Vulnerability Index: Subversive Russian Influence in Central Europe. GLOBSEC Policy Institute 2017 // https://www.globsec.org/wpcontent/uploads/2017/08/globsec-vulnerability-index.pdf
} 
Europe's own political, energetic and information security. This task is not easy but therefore, the most important thing is to make sure that all the EU member-states follow the Brussels-based course. Firstly, Europe should draw certain red lines in relations with Russia and make it clear that their trespassing will not be tolerated. Secondly, the European states should have a common position and vision of what should happen to have sanctions lifted. Besides, the EU member states should consider the application of additional sanctions on Russia in response to human rights violations in Crimea and reputational sanctions for others who support Putin's aggressive behaviour. Thirdly, there should be more awareness on the need to cooperate in order to counter hybrid threats and any interference in the internal affairs of the European countries.

\section{SUMMARY}

The article deals with the assessment how the annexation of Crimea affected Europe's security policy. The research focuses on the EU's response to the annexation of Crimea, as well as examines the post-2014 security policy of the four countries which are the most susceptible to invasion and vulnerable to Russia's influence - Poland, Slovakia, the Czech Republic and Hungary. By taking an interdisciplinary and critical look at the impact the annexation of Crimea made on Europe, the paper aims to provide essential insights on how the annexation of Crimea has impacted the narrative and political decisions in security field adopted by EU and the Visegrad Group states. Several vulnerabilities and challenges to greater cooperation and common approach to security in the region at the EU level and the four member-states' level are identified. At the end of the paper the recommendations on how to ensure Europe's own political, energetic and information security are presented.

\section{REFERENCES}

1. Герасимов В. Ценность науки в предвидении. ВоенноПромыиленный Курьер. 2013. URL: www.vpk-news.ru/articles/14632

2. Annual Report of the Security Information Service of the Czech Republic. 2016. URL: https://www.bis.cz/public/site/bis.cz/content/vyrocnizpravy/en/ar2016en.pdf

3. Benková L. The Rise of Russian Disinformation in Europe. FOKUS. 2018. No 3. URL: https://www.aies.at/download/2018/AIES-Fokus_201803.pdf

4. Council Conclusions on the EU's engagement to the Black Sea regional cooperation of 17 June 2019. URL: https://www.consilium.europa.eu/media/39779/st10219-en19.pdf 
5. Council Conclusions. Brussels on a Framework for a Joint EU Diplomatic Response to Malicious Cyber Activities of 7 June 2017. URL: http://data.consilium.europa.eu/doc/document/ST-9916-2017-INIT/en/pdf

6. Council Decision (CFSP) 2019/797 of 17 May 2019 concerning restrictive measures against cyber-attacks threatening the Union or its Member States. URL: https://eur-lex.europa.eu/legal-content/GA/TXT/ ?uri=CELEX:32019D0797

7. Declaration by the High Representative Federica Mogherini on behalf of the EU on the Autonomous Republic of Crimea and the city of Sevastopol of 17March 2019. URL:https://www.consilium.europa.eu/en/press/pressreleases/2019/03/17/declaration-by-the-high-representative-federicamogherini-on-behalf-of-the-eu-on-the-autonomous-republic-of-crimea-andthe-city-of-sevastopol/

8. Disinformation Resilience in Central and Eastern Europe. Kyiv. 2018. URL: http://prismua.org/wp-content/uploads/2018/06/ DRI_CEE_2018.pdf

9. European Parliament resolution (2017/2283(INI)) on the implementation of the EU Association Agreement with Ukraine of 12 December 2018. URL: http://www.europarl.europa.eu/doceo/document/ TA-8-2018-0518_EN.html?redirect

10. European Parliament resolution $\{2018 / 2870(\mathrm{RSP}))$ on the situation in the Sea of Azov of 24 October 2018. URL: http://www.europarl.europa.eu/doceo/document/RC-8-2018-0493_EN.html

11. European Parliament Resolution of 23 November 2016 on EU Strategic Communication to Counteract Propaganda against it by Third Parties. URL: https://www.europarl.europa.eu/doceo/document/TA-8-20160441_EN.html

12. European Parliament. Disinformation, 'fake news' and the EU's response 2017. URL: http://www.europarl.europa.eu/RegData/etudes/ ATAG/2017/614584/EPRS_ATA(2017)614584_EN.pdf

13. European Values. Open Letter of European security experts to Federica Mogherini: Please start taking the Russian disinformation threat seriously. URL: http://www.europeanvalues.net/mogherini/

14. Extraordinary meeting of EU Heads of State or Government on Ukraine of 6 March 2014. URL: https://www.consilium.europa.eu/en/ meetings/european-council/2014/03/06/

15. Furgacz P. Poland's Military Security Policy in the Context of the Russian Ukrainian War: Change or Continuity, Ante Portas - Studia nad Bezpieczeństwem, 2017. No 1. URL: file:///D:/\%D0\%97\%D0\%B0\%D0\% B3\%D1\%80\%D1\%83\%D0\%B7\%D0\%BA\%D0\%B8/AP.VIII_Furgacz\%20( 1).pdf 
16. Hungary's National Security Strategy. 2012. URL: https://www.eda.europa.eu/docs/default-source/documents/hungarynational-security-strategy-2012.pdf

17. Ivashchenko-Stadnik K., Petrov R., Rieker P., Russo A. Implementation of the EU's crisis response in Ukraine. EUNPACK working paper. 2018. URL: http://www.eunpack.eu/sites/default/files/publications/ 2018-01-31\%20D6.3\%20Working\%20paper\%20on\%20

implementation\%20of\%20EU\%20crisis\%20response\%20in\%20Ukraine.pdf

18. Kalinichenko P. Post-Crimean Twister: Russia, the EU and the Law of Sanctions. Russian Law Journal. 2017. No 5(3). P. 9-28 . URL: https://doi.org/10.17589/2309-8678-2017-5-3-9-28

19. KrekóP., Győri L. Hungary: A State Captured by Russia. Heinrich Böll Foundation. 2017 . URL: https://www.boell.de/en/2017/10/11/hungarystate-captured-russia

20. Kremlin Watch Report. How do European democracies react to Russian aggression? Review of shifts in strategic \& policy documents of EU28 following Russian aggression against Ukraine. 2017. URL: https://www.europeanvalues.net/wp-content/uploads/2017/04/How-doEuropean-democracies-react-to-Russian-aggression.pdf

21. Milo D., Klingova K. Vulnerability Index: Subversive Russian Influence in Central Europe. GLOBSEC Policy Institute. 2017. URL: https://www.globsec.org/wp-content/uploads/2017/08/globsec-vulnerabilityindex.pdf

22. Minister Witold Waszczykowski opens conference on disinformation. MFA. 2016. URL:http://www.msz.gov.pl/en/news/minister_ witold_waszczykowski_opens_conference_on_disinformation

23. Miroslavov $\mathrm{O}$. Poland refuses $\mathrm{LNG}$ terminal in favor of the gas corridor with Norway. RuBaltic. 2018. URL: https://www.rubaltic.ru/ articles/06032018-poland-refuses-lng-terminal-in-favor-of-the-gas-corridorto-norway/

24. National Security Audit. Government of the Czech Republic. 2016. URL: https://www.vlada.cz/assets/media-centrum/aktualne/Auditnarodni-bezpecnosti-20161201.pdf

25. Nečej E., Žilinčík S. Analysis of the draft of Security Strategy of Slovak Republic 2017: Comparison with strategic documents of Czech Republic and Poland. STRATPOL. 2017. URL: // https://www.stratpol.sk/wp-content/uploads/2017/08/fSSSR-2017-ENG-vfinal-OND-final.pdf

26. Polish PM to set up new cybersecurity department. Radio Poland. 2017. URL: http://www.thenews.pl/1/9/Artykul/329562,Polish-PM-to-setup-new-cybersecurity-department 
27. Questions and Answers about the East StratCom Task Force. URL: https://eeas.europa.eu/headquarters/headquarters-homepage/2116/questions-and-answers-about-the-east-stratcom-task-force_en

28. Security Strategy of the Czech Republic. Ministry of Defence \& Armed Forces of the Czech Republic. 2015. URL: http://www.army.cz/ images/id_8001_9000/8503/Security_Strategy_2015.pdf

29. Selhorst T. Russia's Perception Warfare. Militaire Spectator. 2016. URL: https://www.militairespectator.nl/thema/strategieoperaties/artikel/russias-perception-warfare

30. Stone, J. 2018. Russian disinformation campaign has been 'extremely successful' in Europe, warns EU. Independent. 17 January 2018. URL: http://www.independent.co.uk/news/uk/politics/russian-fakenewsdisinformation-europe-putin-trump-eu-european-parliament-commissiona8164526.html

31. Ukraine urges EU to impose new sanctions on Russia over attack near Kerch Strait. UNIAN. 26 November 2018. URL: https://www.unian.info/politics/10351809-ukraine-urges-eu-to-impose-newsanctions-on-russia-over-attack-near-kerch-strait.html

32. Ukraine: EU responds to escalation at the Kerch Strait and the Sea of Azov, and renews sanctions over actions against Ukraine's territorial integrity of 15 March 2019. URL: https://www.consilium.europa.eu/ en/press/press-releases/2019/03/15/ukraine-eu-responds-to-escalation-at-thekerch-straits-and-the-azov-sea-and-renews-sanctions-over-actions-againstukraine-s-territorial-integrity/

33. Yuhas A. Russian Propaganda over the Crimea and the Ukraine: How Does it Work? The Guardian of 17 March 2014. URL: https://www.theguardian.com/world/2014/mar/17/the The the Crimea-crisisrussia-propaganda-media

\section{Information about the author: Dvornichenko D., $\mathrm{PhD}$ in Political Sciences,} Associate Professor at the Department of Maritime Law of the National University «Odesa Maritime Academy» 8, Didrikhson str., Odesa, 65029, Ukraine 